Research Article

\title{
Genotoxicity biomonitoring of sewage in two municipal wastewater treatment plants using the Tradescantia pallida var. purpurea bioassay
}

\author{
Márcia Regina Thewes ${ }^{1}$, Delio Endres Junior ${ }^{2}$ and Annette Droste ${ }^{3}$ \\ ${ }^{1}$ Departamento Municipal de Água e Esgotos, Divisão de Pesquisa, Porto Alegre, RS, Brazil. \\ ${ }^{2}$ Laboratório de Biotecnologia Vegetal, Instituto de Ciências da Saúde, Universidade Feevale, \\ Novo Hamburgo, RS, Brazil. \\ ${ }^{3}$ Programa de Pós-Graduação em Qualidade Ambiental, Universidade Feevale, Novo Hamburgo, \\ RS, Brazil.
}

\begin{abstract}
The genotoxicity of untreated and treated sewage from two municipal wastewater treatment plants (WTP BN and WTP SJN) in the municipality of Porto Alegre, in the southern Brazilian state of Rio Grande do Sul, was evaluated over a one-year period using the Tradescantia pallida var. purpurea (Trad-MCN) bioassay. Inflorescences of $T$. pallida var. purpurea were exposed to sewage samples in February (summer), April (autumn), July (winter) and October (spring) 2009, and the micronuclei (MCN) frequencies were estimated in each period. The high genotoxicity of untreated sewage from WTP BN in February and April was not observed in treated sewage, indicating the efficiency of treatment at this WTP. However, untreated and treated sewage samples from WTP SJN had high MCN frequencies, except in October, when rainfall may have been responsible for reducing these frequencies at both WTPS. Physicochemical analyses of sewage from both WTPs indicated elevated concentrations of organic matter that were higher at WTP SJN than at WTP BN. Chromium was detected in untreated and treated sewage from WTP SJN, but not in treated sewage from WTP BN. Lead was found in all untreated sewage samples from WTP SJN, but only in the summer and autumn at WTP BN. These results indicate that the short-term Trad-MCN genotoxicity assay may be useful for regular monitoring of municipal WTPs.
\end{abstract}

Key words: effluent, micronucleus, mutagenicity, pollution, Trad-MCN.

Received: December 17, 2010, Accepted: September 20, 2011.

\section{Introduction}

The sewage produced in urban centers contains numerous pollutants from domestic and industrial sources, and treated sewage may contain complex mixtures of organic and inorganic compounds that may not be degraded during treatment (Rank and Nielsen, 1998). Several studies have investigated the genotoxicity of industrial effluents (Houk, 1992; Ruiz et al., 1992; Nielsen and Rank, 1994; Rodrigues et al., 2010) and the water bodies that receive them (Ohe et al., 2004; Mitteregger et al., 2007; Umbuzeiro et al., 2007). The sewage sludge from municipal treatment plants has also been tested for toxicity and genotoxicity (Hopke et al., 1984; Ottaviani et al., 1993; Rank and Nielsen, 1998; Mielli et al., 2009). However, liquid effluents from municipal sewage plants have been evaluated using chemical analyses primarily to meet legal obligations, and

Send correspondence to Annette Droste. Programa de Pós-Graduação em Qualidade Ambiental, Universidade Feevale, Rodovia RS 239, Caixa Postal 2755, 93352-000 Novo Hamburgo, RS, Brazil. E-mail: annette@feevale.br. less attention has been paid to their genotoxic effects on organisms (Grisolia et al., 2005).

In 2006, the Brazilian state of Rio Grande do Sul issued a regulation to establish criteria for the release of domestic and industrial liquid effluents into the environment based on their toxicity, genotoxicity and type of sewage (CONSEMA, 2006a). Over the next 8-12 years, the state environmental control agencies will define the test organisms and protocols to be used in monitoring these effluents.

The Tradescantia micronucleus (Trad-MCN) assay, a sensitive test for evaluating genotoxicity (Crebelli et al., 2005; Rodrigues et al., 1997), is based on the small chromatin masses derived from chromosomal breakages or aneuploidy during meiosis of the pollen mother cells (Ma et al., 1984). Clone \#4430, a hybrid of T. subacaulis Bush and T. hirsutiflora Bush, has been successfully used for bioassays (Ma et al., 1994). On the other hand, Tradescantia pallida (Rose) D. R. Hunt var. purpurea Boom is an appropriate alternative for genotoxicity testing because it is well adapted to and extensively cultivated in tropical and subtropical regions (Batalha et al., 1999). 
In this work, we used the Trad-MCN assay to evaluate and compare the genotoxicities of untreated and treated sewage from two municipal wastewater treatment plants (WTPs) over a one-year period.

\section{Materials and Methods}

\section{Sampling sites and collection of sewage samples}

Untreated and treated sewage samples from two WTPs were evaluated. The plants are located in the hydrographic basin of Guaíba Lake, in the southern Brazilian state of Rio Grande do Sul, and receive wastewater from the municipality of Porto Alegre; both are operated by the Municipal Department of Water and Sewage (DMAE). WTP $\mathrm{SJN}$ is located in a densely populated urban area with commercial and industrial activities. The sewage is treated by biological oxidation using an activated sludge process followed by aerated lagoon treatment at a mean flow rate of $246 \mathrm{~L} / \mathrm{s}$ (range: 146-323 L/s). WTP BN is located in a less populated urban residential area and the sewage is treated in conventional, Australian-type stabilization lagoons at a mean flow rate of $23 \mathrm{~L} / \mathrm{s}$ (range: 8-60 L/s).

In February, April, July and October 2009 (representing summer, autumn, winter and spring, respectively), untreated and treated sewage samples were collected from both sampling sites, transported to the laboratories where the experiments were done and preserved according to criteria established by the Brazilian Association of Technical Standards (ABNT - NBR 9898).

\section{Physicochemical analyses}

Untreated and treated sewage samples from both WTPs were collected for physicochemical analyses at the intervals indicated above. For each sewage sample collected the biochemical oxygen demand (BOD), chemical oxygen demand (COD), total suspended solid (TSS), total nitrogen (TN), total phosphorus (TP) and heavy metal content were measured. The parameters tested included some of those used in monitoring the efficiency of the WTPs operated by the DMAE, in accordance with the standard recommendations of the State Foundation for Environmental Protection (FEPAM) and the quality criteria of the State Environmental Council (CONSEMA, 2006a,b). The samples were analyzed using the methods described by the APHA (2005). Metals were analyzed by using inductively-coupled plasma optical emission spectrometry (ICP-OES) (USEPA, 2001). All analyses were done in the research division of DMAE, in Porto Alegre. Rainfall data were obtained from the Defesa Civil - Rio Grande do Sul (Defesa Civil, 2010).

\section{Trad-MCN bioassay}

Samples of Tradescantia pallida var. purpurea were grown in pots $(37 \mathrm{~cm} \times 20 \mathrm{~cm} \times 20 \mathrm{~cm}$ ) containing $4 \mathrm{~kg}$ of commercial soil from the same batch, in a non-polluted area of Feevale University. The plants were watered three times a week. Once a week, $100 \mathrm{~mL}$ of 1/3-strength Hoagland solution was applied to each pot and $100 \mathrm{~mL}$ of an N-P-K fertilizer solution $(10-10-10, \mathrm{w} / \mathrm{w} / \mathrm{w})$ was applied once a month.

Plant exposure, inflorescence fixation and storage, slide preparation and data analysis were done using a modified version of the protocol described by Ma et al. (1984). Cuttings collected from the plant stocks bearing young inflorescences were maintained partially immersed in distilled water for $24 \mathrm{~h}$ in groups of 15 to 20 . After this period of adaptation, only turgid cuttings were exposed to the following samples for $8 \mathrm{~h}$ : (a) untreated sewage, (b) treated sewage, (c) $0.1 \%$ formaldehyde solution (positive control) and (d) distilled water (negative control). Treatment was followed by a $24 \mathrm{~h}$ recovery period in distilled water. The inflorescences were fixed in 3:1 (v/v) ethanol/acetic acid for $24 \mathrm{~h}$ and stored in 70\% ethanol. One bud per inflorescence was dissected and the anthers were squashed in $1 \%$ acetocarmine stain on a slide. Only preparations with early tetrads were included in the analysis. Seven slides were prepared for each sample. The slides were coded and the number of MCN in a random set of 300 tetrads per slide was scored under 400x magnification (Olympus CX4 microscope). The MCN frequencies were calculated by dividing the total number of micronuclei by the total number of tetrads scored, and the results were expressed as MCN/100 tetrads. All of the experiments were done in the Laboratory of Plant Biotechnology at Feevale University.

\section{Statistical analysis}

The Trad-MCN bioassay data were analyzed using the software package SPSS 17.0 after initial natural logarithm $(\mathrm{ln})$ data transformation to obtain a normal distribution of variables and homogenous variances. The MCN frequencies of the samples in each of the four months were subsequently compared by one-way ANOVA followed by the Tukey test for multiple comparisons. Values of $p<0.05$ indicated significance.

\section{Results}

Tables 1 and 2 show the physicochemical properties of the samples collected from WTP SJN and WTP BN for genotoxicity evaluation during the four seasons of 2009. The biochemical oxygen demand (BOD) met legal criteria, except at WTP SJN in the summer and winter. Total suspended solid (TSS) values were above the maximum permitted, except in the winter at WTP BN and WTP SJN and in the summer at WTP SJN. WTP BN satisfactorily removed total nitrogen (TN) in the summer and autumn, whereas the removal at WTP SJN was unsatisfactory in all seasons. The total phosphorus (TP) concentrations were higher than recommended at both WTPs in all seasons except at WTP BN in the spring. 
Tables 1 and 2 also show the heavy metal concentrations in the sewage samples. Chromium $(\mathrm{Cr})$ was detected in untreated and treated sewage from WTP SJN in all seasons except the winter, when it was undetectable in treated sewage. In contrast, at WTP BN, low concentrations of this metal were detected in untreated sewage samples only in the summer and autumn, and no chromium was found in treated sewage. Lead $(\mathrm{Pb})$ was found in all untreated sewage samples from WTP SJN, but was only found at WTP $\mathrm{BN}$ in the summer and autumn.

The MCN frequencies of untreated sewage samples from WTP BN were significantly higher than those of the negative control in the summer and autumn, whereas treated sewage did not differ significantly from the negative control throughout the monitoring period (Figure 1). In contrast, the $\mathrm{MCN}$ frequency in plants exposed to untreated sewage from WTP SJN was significantly higher than in the negative con- trol in all seasons, except spring. At this WTP, treated sewage samples had high MCN frequencies that were equal to or greater than those in positive control samples, except in the spring. The MCN frequencies in untreated sewage from both WTPs were lower in the spring than in other seasons and did not differ from the negative control. Except in the spring, when all samples had low MCN frequencies, treated sewage from WTP SJN was significantly more genotoxic than treated sewage from WTP BN.

\section{Discussion}

Effluents from municipal sewage treatment plants have been tested for mutagenicity using the Salmonella/microsome test (Meier et al., 1987), the polychaete Platynesis dumerilli (Jha et al., 1997), Allium cepa (Nielsen and Rank, 1994; Grisolia et al., 2005) and fish (Grisolia et

Table 1 - Physicochemical characteristics of the WTP BN sewage samples in four seasons of 2009.

\begin{tabular}{|c|c|c|c|c|c|c|c|c|c|}
\hline \multirow[t]{2}{*}{ Parameter $^{1}$} & \multicolumn{2}{|c|}{$\begin{array}{c}\text { February } 2009 \\
\text { (Summer) Sewage }\end{array}$} & \multicolumn{2}{|c|}{$\begin{array}{c}\text { April } 2009 \\
\text { (Autumn) Sewage }\end{array}$} & \multicolumn{2}{|c|}{$\begin{array}{c}\text { July } 2009 \\
\text { (Winter) Sewage }\end{array}$} & \multicolumn{2}{|c|}{$\begin{array}{c}\text { October } 2009 \\
\text { (Spring) Sewage }\end{array}$} & \multirow[t]{2}{*}{$\begin{array}{l}\text { Emission } \\
\text { pattern }^{2}\end{array}$} \\
\hline & Untreated & Treated & Untreated & Treated & Untreated & Treated & Untreated & Treated & \\
\hline $\mathrm{COD}(\mathrm{mg} / \mathrm{L})$ & $n e^{3}$ & ne & 209.4 & 114.2 & 242.8 & 130.6 & 111.0 & 135.0 & 260.0 \\
\hline $\mathrm{TSS}(\mathrm{mg} / \mathrm{L})$ & 92.0 & 104.0 & 520.0 & 414.0 & 71.0 & 44.0 & 74.0 & 82.0 & 80.0 \\
\hline $\mathrm{TN}(\mathrm{mg} / \mathrm{L})$ & 46.20 & 11.07 & 49.92 & 10.49 & 47.36 & 17.33 & 16.52 & 8.73 & 15.0 \\
\hline $\mathrm{TP}(\mathrm{mg} / \mathrm{L})$ & 6.05 & 2.43 & 7.77 & 3.73 & 7.43 & 2.42 & 3.17 & 1.69 & 2.0 \\
\hline $\mathrm{Pb}(\mathrm{mg} / \mathrm{L})$ & 0.0030 & $\mathrm{nd}^{4}$ & 0.0072 & 0.0037 & nd & nd & nd & nd & 0.2 \\
\hline $\mathrm{Cu}(\mathrm{mg} / \mathrm{L})$ & 0.0160 & nd & 0.0161 & 0.0004 & 0.0099 & 0.0043 & 0.0088 & 0.0023 & 0.5 \\
\hline $\mathrm{Cr}(\mathrm{mg} / \mathrm{L})$ & 0.0002 & nd & 0.0006 & nd & nd & nd & nd & nd & 0.5 \\
\hline $\mathrm{Cd}(\mathrm{mg} / \mathrm{L})$ & nd & nd & nd & nd & nd & nd & nd & nd & 0.1 \\
\hline $\mathrm{Hg}(\mathrm{mg} / \mathrm{L})$ & nd & nd & 0.0001 & 0.0001 & 0.0001 & 0.0020 & nd & 0.0014 & 0.1 \\
\hline
\end{tabular}

${ }^{1} \mathrm{BOD}=$ biochemical oxygen demand, $\mathrm{COD}=$ chemical oxygen demand, $\mathrm{TSS}=$ total suspended solids, $\mathrm{TN}=$ total nitrogen, $\mathrm{TP}=$ total phosphorus, $\mathrm{Pb}=$ lead, $\mathrm{Cu}=$ cupper, $\mathrm{Cr}=$ chromium, $\mathrm{Cd}=$ cadmium, $\mathrm{Hg}=$ mercury, $\mathrm{Zn}=$ zinc. ${ }^{2}$ According to CONSEMA (2006b). ${ }^{3}$ ne $=$ not evaluated. ${ }^{4}$ nd $=$ not detected.

Table 2 - Physicochemical characteristics of the WTP SJN sewage samples in four seasons of 2009.

\begin{tabular}{|c|c|c|c|c|c|c|c|c|c|}
\hline \multirow[t]{2}{*}{ Parameter $^{1}$} & \multicolumn{2}{|c|}{$\begin{array}{c}\text { February } 2009 \\
\text { (Summer) Sewage }\end{array}$} & \multicolumn{2}{|c|}{$\begin{array}{c}\text { April } 2009 \\
\text { (Autumn) Sewage }\end{array}$} & \multicolumn{2}{|c|}{$\begin{array}{c}\text { July } 2009 \\
\text { (Winter) Sewage }\end{array}$} & \multicolumn{2}{|c|}{$\begin{array}{c}\text { October } 2009 \\
\text { (Spring) Sewage }\end{array}$} & \multirow[t]{2}{*}{$\begin{array}{c}\text { Emission } \\
\text { pattern }^{2}\end{array}$} \\
\hline & Untreated & Treated & Untreated & Treated & Untreated & Treated & Untreated & Treated & \\
\hline $\mathrm{BOD}(\mathrm{mg} / \mathrm{L})$ & 325.0 & 52.0 & 221.0 & 17.3 & 182.0 & 45.0 & 184.0 & 27.0 & 40.0 \\
\hline $\mathrm{COD}(\mathrm{mg} / \mathrm{L})$ & 639.0 & $\mathrm{ne}^{3}$ & 227.9 & 39.4 & 419.2 & 96.4 & 340.0 & 81.0 & 150.0 \\
\hline TSS (mg/L) & 424.0 & 14.0 & 474.0 & 400.0 & 128.0 & 37.0 & 438.0 & 71.0 & 50.0 \\
\hline $\mathrm{TN}(\mathrm{mg} / \mathrm{L})$ & 49.37 & 18.18 & 43.33 & 18.63 & 36.10 & 21.71 & 20.20 & 10.63 & 10.0 \\
\hline $\mathrm{TP}(\mathrm{mg} / \mathrm{L})$ & 12.00 & 1.49 & 5.45 & 4.80 & 5.35 & 3.46 & 2.19 & 1.24 & 1.0 \\
\hline $\mathrm{Pb}(\mathrm{mg} / \mathrm{L})$ & 0.03500 & $\mathrm{nd}^{4}$ & 0.00020 & nd & 0.01600 & 0.00063 & 0.01218 & nd & 0.2 \\
\hline $\mathrm{Cu}(\mathrm{mg} / \mathrm{L})$ & 0.15240 & 0.00365 & 0.01610 & 0.00560 & 0.02325 & 0.00575 & 0.03998 & 0.00840 & 0.5 \\
\hline $\mathrm{Cr}(\mathrm{mg} / \mathrm{L})$ & 0.08815 & 0.00084 & 0.00240 & 0.00150 & 0.00350 & nd & 0.00604 & 0.00051 & 0.5 \\
\hline $\mathrm{Cd}(\mathrm{mg} / \mathrm{L})$ & 0.00130 & nd & nd & nd & nd & nd & nd & nd & 0.1 \\
\hline $\mathrm{Hg}(\mathrm{mg} / \mathrm{L})$ & 0.00080 & 0.00010 & 0.00010 & 0.00010 & nd & nd & 0.00140 & 0.00130 & 0.1 \\
\hline $\mathrm{Zn}(\mathrm{mg} / \mathrm{L})$ & 0.43560 & 0.03064 & 0.04280 & 0.03610 & 0.05875 & 0.30000 & 0.17693 & 0.03953 & 2.0 \\
\hline
\end{tabular}

${ }^{1} \mathrm{BOD}=$ biochemical oxygen demand, $\mathrm{COD}=$ chemical oxygen demand, $\mathrm{TSS}=$ total suspended solids, $\mathrm{TN}=$ total nitrogen, $\mathrm{TP}=$ total phosphorus, $\mathrm{Pb}=$ lead, $\mathrm{Cu}=$ cupper, $\mathrm{Cr}=$ chromium, $\mathrm{Cd}=$ cadmium, $\mathrm{Hg}=$ mercury, $\mathrm{Zn}=$ zinc. ${ }^{2}$ According to CONSEMA $(2006 \mathrm{~b}) .{ }^{3}$ ne $=$ not evaluated. ${ }^{4}$ nd $=$ not detected. 
al., 2005). However, Tradescantia is apparently more sensitive to genotoxic substances than Allium cepa, a widely used bioindicator of water quality (Crebelli et al., 2005). In contrast, there have been no reports on the use of T. pallida var. purpurea to test untreated and treated sewage from WTPs. Tradescantia pallida var. purpurea has been successfully used to evaluate genotoxicity by in situ exposure in a Brazilian river (Umbuzeiro et al., 2007) and by long-term exposure to treated sludge samples from WTPs in the State of São Paulo (Mielli et al., 2009), with the latter study showing that this organism is as sensitive as clone \#4430.

For samples from WTP BN, the high genotoxicity of untreated sewage was not observed in treated sewage. In contrast, both untreated and treated sewage samples from WTP SJN had high MCN frequencies. In general, the values of the physicochemical parameters for treated sewage from WTP BN were below the legal emission limits, whereas the corresponding values for WTP SJN were higher. The total nitrogen and total phosphorus concentrations of samples from WTP SJN were above the legal limits. Of all the metals analyzed, chromium was detected in more seasons and at higher concentrations in samples from WTP SJN than in those from WTP BN. These differences in the physicochemical characteristics between the two
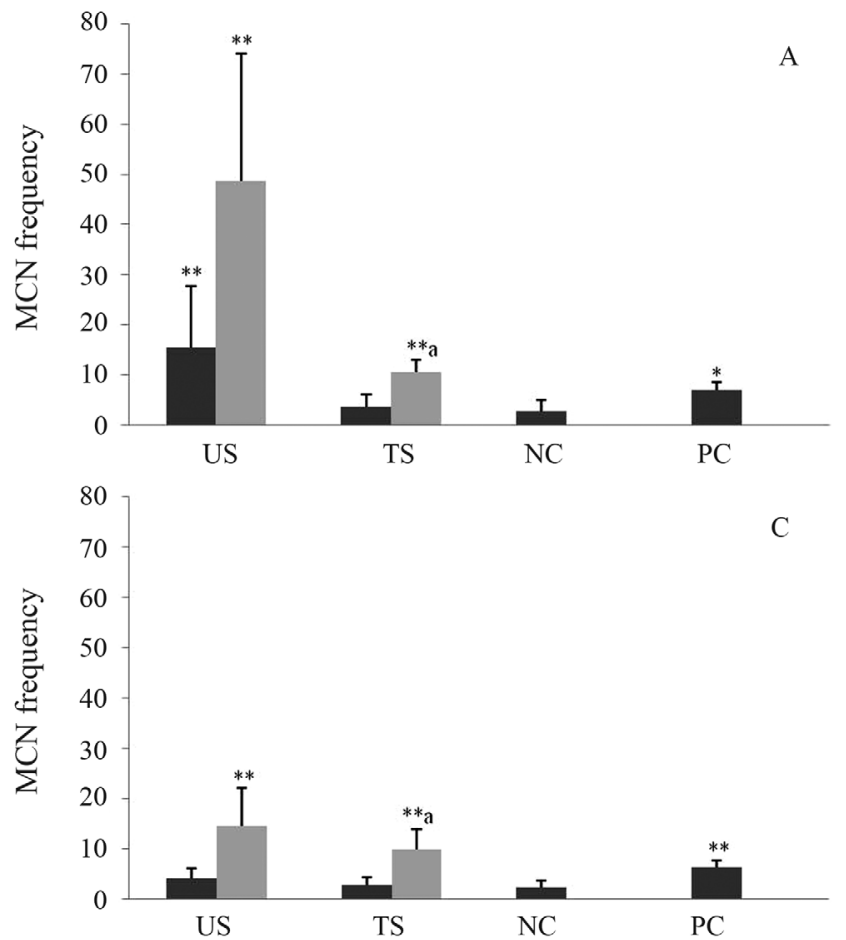

WTPs may have influenced the MCN frequencies, which were higher for WTP SJN.

Industrial effluents containing chemicals other than those included in our tests may have been released unexpectedly into the sewer system, which was built to treat only domestic sewage. In large metropolitan areas, sewage from different sources may form complex mixtures that have marked effects on organisms (White and Rasmussen, 1998), and sludge from domestic sewage is less genotoxic than that from other sources (Hopke et al., 1984). Heavy metals in different substrates can induce micronuclei in Tradescantia (Majer et al., 2002). However, in the present study, we did not identify which chemicals were responsible for genotoxicity. Further studies should investigate how the complex mixtures of pollutants influence micronucleus formation.

In the spring, the MCN frequencies of untreated and treated sewage from both WTPs were not significantly different from the negative control. These findings may be explained by the cumulative volume of rainfall during the four days before sampling. In the first three seasons of the year, rainfall before sampling was zero or very close to zero, but was much higher $(37.6 \mathrm{~mm})$ in the spring and may have diluted the sewage. These findings indicate that monitoring should be done at various time points throughout the year. Furthermore, tests should include both untreated and
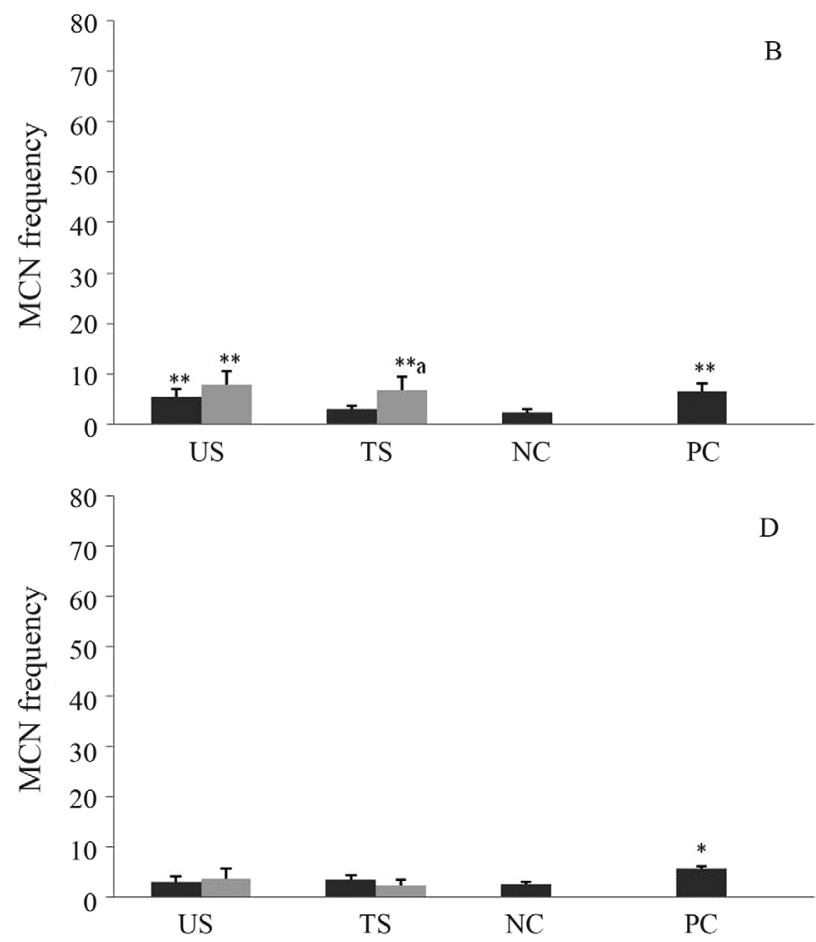

Figure 1 - Frequency of micronuclei (MCN) in tetrads of Tradescantia pallida var. purpurea obtained during monitoring of untreated and treated sewage samples from two wastewater treatment plants (black column = WTP BN; gray column = WTP SJN) in the summer (A), autumn (B), winter (C) and spring (D) of 2009. $\mathrm{NC}=$ negative control, $\mathrm{PC}=$ positive control, TC $=$ treated sewage and US = treated sewage. The columns are the mean $\pm \mathrm{SD}$. Asterisks indicate significant $(* \mathrm{p}<0.05)$ and highly significant $(* * \mathrm{p}<0.001)$ differences compared to the negative control (ANOVA followed by the Tukey test). The letter "a" indicates a significant difference $(\mathrm{p}<0.001)$ compared to WTP BN treated sewage in the same month (ANOVA followed by the Tukey test). 
treated sewage to determine whether the test organism is a suitable bioindicator for the samples under evaluation. Otherwise, it may be unclear whether negative results are indicative of a lack of genotoxicity or simply reflect the low sensitivity of the bioindicator used to test the samples.

Our results indicate that this short-term assay is a useful tool for assessing the genotoxicity of sewage. Future studies should evaluate its efficiency in the regular monitoring of municipal WTPs.

\section{Acknowledgments}

This work is part of a Master's dissertation by Márcia Regina Thewes and was supported by grants from Feevale University and the Municipal Department of Water and Sewage (DMAE) of Porto Alegre, Brazil. The authors thank DMAE for providing field facilities and Scientific Linguagem for editing the English of the manuscript.

\section{References}

APHA (American Public Health Association) (2005) Standard Methods for the Examination of Water and Wastewater. 21st edition. American Public Health Association, Washington DC, $1220 \mathrm{pp}$.

Batalha JRF, Guimarães ET, Lobo DJA, Lichtenfels AJFC, Deur T, Carvalho HA, Alves ES, Domingos M, Rodrigues GS and Saldiva PHN (1999) Exploring the clastogenic effects of air pollutants in São Paulo (Brazil) using the Tradescantia micronuclei assay. Mutat Res 426:229-232.

CONSEMA (Conselho Estadual do Meio Ambiente - Rio Grande do Sul) (2006a) Resolução no. 129. Legislation date: 24/11/2006, Publication DOE: 08/12/2006.

CONSEMA (Conselho Estadual do Meio Ambiente - Rio Grande do Sul) (2006b) Resolução no. 128. Legislation date: 24/11/2006, Publication DOE: 08/12/2006.

Crebelli R, Conti L, Monarca S, Feretti D, Zerbini I, Zani C, Veschetti E, Cutilli D and Ottaviani M (2005) Genotoxicity of the disinfection by-products resulting from peracetic acid- or hypochlorite-disinfected sewage wastewater. Water Res 39:1105-1113.

Grisolia CK, Oliveira ABB, Bonfim H and Klautau-Guimarães MN (2005) Genotoxicity evaluation of domestic sewage in a municipal wastewater treatment plant. Genet Mol Biol 28:334-338.

Hopke PK, Plewa MJ, Stapleton PL and Weaver DL (1984) Comparison of the mutagenicity of sewage sludges. Environ Sci Technol 18:909-916.

Houk VS (1992) The genotoxicity of industrial wastes and effluents. Mutat Res 277:91-138.

Jha AN, Hutchinson TH, Mackay JM, Elliott BM and Dixons DR (1997) Evaluation of the genotoxicity of municipal sewage effluent using the marine worm Platynereis dumerilii (Polychaeta, Nereidae). Mutat Res 391:179-188.

Ma TH, Anderson VA, Harris MM, Neas RE and Lee TS (1984) Mutagenicity of drinking water detected by the Tradescantia-micronucleus test. Can J Genet Cytol 27:143-150.

Ma TH, Cabrera GL, Chen R, Gill BS, Sandhu SS, Vandenberg AL and Salamone MF (1994) Tradescantia micronucleus bioassay. Mutat Res 310:221-230.
Majer BJ, Tscherko D, Paschke A, Wennrich R, Kundi M, Kandeler E and Knasmüller S (2002) Effects of heavy metal contamination of soils on micronucleus induction in Tradescantia and on microbial enzyme activities: A comparative investigation. Mutat Res 515:111-124.

Meier JR, Blazac WF, Riccio ES, Stewart BE, Bishop DF and Condie LW (1987) Genotoxic properties of municipal wastewaters in Ohio. Arch Environ Contam Toxicol 16:671-680.

Mielli AC, Matta MEM, Nersesyan A, Saldiva PHN and Umbuzeiro GA (2009) Evaluation of the genotoxicity of treated urban sludge in the Tradescantia micronucleus assay. Mutat Res 672:51-54.

Mitteregger HMJ, Silva J, Arenzon A, Portela CS, Ferreira ICFS and Henriques JAP (2007) Evaluation of genotoxicity and toxicity of water and sediment samples from a Brazilian stream influenced by tannery industries. Chemosphere 67:1211-1217.

Nielsen MH and Rank J (1994) Screening of toxicity and genotoxicity in wastewater by the use of the Allium test. Hereditas 121:249-254.

Ohe T, Watanabeb T and Wakabayashi K (2004) Mutagens in surface waters: A review. Mutat Res 567:109-149.

Ottaviani M, Crebelli R, Fuselli S, Rocca CL and Baldassarri LT (1993) Chemical and mutagenic evaluation of sludge from a large wastewater treatment plant. Ecotoxicol Environ Saf 26:18-32.

Rank J and Nielsen MH (1998) Genotoxicity of wastewater sludge using the Allium cepa anaphase-telophase chromosome aberration assay. Mutat Res 418:113-119.

Rodrigues FP, Angeli JPF, Mantovani MS, Guedes CLB and Jordão BQ (2010) Genotoxic evaluation of an industrial effluent from an oil refinery using plant and animal bioassays. Genet Mol Biol 33:169-175.

Rodrigues GS, Ma TH, Pimental D and Weinstein LH (1997) Tradescantia bioassays as monitoring systems for environmental mutagenesis: A review. Crit Rev Plant Sci 16:325-359.

Ruiz EF, Rabago VME, Lecona SU, Perez AB and Ma TH (1992) Tradescantia-micronucleus (Trad-MCN) bioassay on clastogenicity of wastewater and in situ monitoring. Mutat Res 270:45-51.

Umbuzeiro GA, Coimbrão CA, Kummrow F, Lobo DJA and Saldiva PHN (2007) Mutagenic activity assessment of Cristais River, São Paulo, Brazil, using the blue rayon/Salmonella microsome and the Tradescantia pallida micronuclei assays. J Braz Soc Ecotoxicol 2:163-171.

USEPA (United States Environmental Protection Agency) (2001) Trace elements in water, solids and biosolids by inductively coupled plasma-atomic emission spectrometry - 200.7. USEPA, Washington DC, $65 \mathrm{pp}$.

White PA and Rasmussen JB (1998) The genotoxic hazards of domestic wastes in surface waters. Mutat Res 460:223-236.

\section{Internet Resources}

Defesa Civil, http://www2.defesacivil.rs.gov.br/estatistica/ pluviometro_consulta.asp (October 12, 2010).

\section{Associate Editor: Catarina S. Takahashi}

License information: This is an open-access article distributed under the terms of the Creative Commons Attribution License, which permits unrestricted use, distribution, and reproduction in any medium, provided the original work is properly cited. 